\title{
The Troyan Terrorism as an Established Order (Disciplina), or the Nomadic Colonatus(Mission of Mith in the space of Sir Thomas More’s “Utopia”)
}

\author{
Menshikova Elena Rudolfovna \\ Expert New Institute for Cultural Research, Moscow, Russia
}

\begin{abstract}
The Troyan horse served here as a sufficiently vivid picture to enter into the history conflicts of an archetypal symbol of treachery and robbery, a metaphor for domination, a monad of violence and its justification. The body of terrorism rests not on ideology/beliefs/religions_-it is purely a practical idea, behind which there is only one thing: terra nova - the habitat. It is necessary to look for other reasons for the massacres and public executions of modern times, because no religion calls for open murder-only dogmatists armed with faith, craved crusaders hikes, and therefore cannot be recognized and accepted as responsible for the murder. This is the search for the guilty, but only the person is guilty-the fault is his area of responsibility. The Utopians of Thomas More, who revered Mithra, acted like him: like Greek gods, they interfered in human wars, descending from heaven, and restored justice by waging war beyond their state borders, as if protecting the inviolability of their territory and their laws, whose rejection, like, and encroachment on them, led to armed conflicts, the purpose of allowing them was the introduction of forced disciplina (established order), sanctioned by Mithra himself. It is this identity that allows us to consider Utopia as an extended invective for the entire social order, regardless of time and place, and in particular the state as a paramilitary mechanism for the improvement of the human hostel, based on regulations that allow and, more often, provoke its violation, since destabilization is the driving force of existence. This polar involvement of Mithra in the war lies hidden in the very aporia of the world-war, which turns the god of treaties into the chthonic deity of destruction and murder.
\end{abstract}

Keywords: Troy, terra, colonatus, nomadic piracy, disciplina,Thomas More, Mithra, state

\section{Introduction}

Let us return to the thread of the story of the "Trojan Terrorism", outstretched from Moscow to London at last year's October conference, interrupted somewhat because of its twist, but only because of its length, suggesting the thesis: Orientalism as a political strategy arose long before its classical paradigm, scientifically justifying the craving for missionary work and colonization, covering the thirst for power and money-grubbing with love for art and humanism. Thucydides, completing his story of the permanent migrations of the Hellenes by passage about Trojan War as a starting point of these movements, makes it clear that the military campaign under Troy was the first militarized journey that accustomed the ancient Greeks, absorbing new spaces,

Menshikova Elena Rudolfovna, Candidate of Cultural Research, Expert New Institute for Cultural Research (Non-governmental organization for development of projects and research in culture and the arts). 
mastering and remaking them to their own needs. The double ax of Troy is the most common weapon in the Mediterranean region of the 1st millennium B.C. (His image was retained by a red-figured vase kept in the British Museum), like the final explosion—a horse stuffed with a rearguard, thrown by the Achaeans near the Asia Minor coasts, legalized the militant art as a mode of existence, retaining for war, in view of its duality, or “double bottom”, the right to contradiction. Trojan horse served by a bright enough picture to enter the history of the conflicts of archetypal symbol of cunning and robbery, significant metaphor of dominance, the Monad of violence and its justification.

Let us turn to the statement of the problem - the self-presentation of terror. Note that the body of terrorism rests not on ideology/beliefs/religions - it is exclusively a practical idea, behind which there is only one thing: terra nova - the habitat. To give a shade of orientalism to the course of thought, let us introduce by melted milk the historical context from my works "The Receptive Curse of Utopia” and “The Journey as a Gene of European Culture" written more than 10 years ago, one published and the other just to be printed (Menshikova, 2012; 2016; 2018a).

The reconstruction of the battering implement of the ancient Greeks allows not only to judge about the technical characteristics of the army and combat equipment ("polyoryka"- the ancient martial art of the siege of the cities, which is described sufficiently and detailed by Apollodorus, Athenaeus, Vegetius ${ }^{1}$ ), but also to admit that the Trojan horse was a forerunner of such weapons, without which then no one siege of the city no maked a shift, and the siege "machines" resembled a horse in its outline.Filled with a brave rearguard and special forces of thugs, a wooden horse on wheels was rolled into Troy and exploded by the first prehistoric bomb, sweeping the city and the kingdom of Danae into flinders, “alive” trotyl: Odysseus's "fur-seals” pricked, cut, and tore methodically and noiselessly all living things on his way, ignoring the borders and the facet of permitted, clearing out Ilium from his citizens, as if it were their territory. De jure and de facto, this was the first act of terrorism, promulgated by the people's "mass media" on the entire planet, beginning with Homer, and replicated by art (all kinds), and as a "pirate method”, borrowed from the world of flora and fauna, was adopted as a means of resolving conflicts, as a dominant force and superiority, by method of intimidation and blackmail. Sown panic and fear serve only one purpose - to occupy and expel from the territory. Tactical trick of the king of Ithaca was a desk reading in the "science of winning", without which neither Alexander nor Caesar and Trajan would have become successful and great generals. Now we justify their ability to ignore the boundaries of the Stranger, their ability to overcome the illicit, sometimes admiring their determination and stubbornness, with which they led their troops to their goal-alien space. But the rules are not set by usand history like evolution has been established and is being made by simple domination, by the right of the "first night", which could care less about borders.

In view of the brevity of the established format, leaving the fervor of reconstruction, we proceed to the preparation of our frog - the "nomadic colonatus", dismantling the metaphor for denotatum, and try to understand "wherewith is it breathe" and first turn on the light bulb to illuminate the entire procedure: in the preface of Utopia reminiscent reference to the bilingualism of Dionysius of Halicarnassus, who enthusiastically pursues his understanding of "civil society" as "citizenship", soldered together by a single ethos that does not violate the boundaries of personal freedom and by international law that provides both freedom and duties before the society on the basis of property rights [Dionysius of Halicarnassus. 2005. II.6.1;16.1;8.2;7.2; 8.1; 8.3;

\footnotetext{
${ }^{1}$ Greek polyortics. Vegetius. St. Petersburg: Aletheia, 1995.
} 
9.1], allows to assume that the practicing lawyer Thomas More wrote in Latin, because the primary sources of his reflections - the books of Dionysius, Caesar, Cicero, Plato, Sallust-emerged from the cultural "non-existence” in Roman sandals, which was quite convenient at quoting author's sentences and own periphrases to the future governor of London, and therefore the Graeco-Roman bilingualism and dichotomy of the ancient political philosophy, allowing to synthesize ideas about the state and the civil community of philosophers and practitioners of the 1st millennium BC, provoke More to create a precedent-writing a political pamphlet, vested in hoops of comparative biographies, but under the umbrella of the Socratic dialogue about the contradictions in the English society of the Reformation period, presenting its "experience of adogmatic thinking” to the society.

The subsequent typological convergence of the More’s "Utopia” with the Dionysius's "Roman antiquities" allowed me to conclude that there is a semantic and stylistic (up to direct borrowing of the official name-the Greek phylarch) coincidence in describing the structure of the state structure, from which it follows that the Utopians inherited the Greek vertical of power that does not exclude a national vote based on the exclusive knowledge of legislative acts by all citizens, and which has developed a system of laws directing State to "prudence and moderation”, non-excluding “care about their own benefit”, and the system of executive power, which operated strictly according to law, with rigorous observance of treaty obligations, which include the principle of trust as the fundamental in relations between citizens.At the same time, it is found that the Utopians were not deprived of private property, owned land allotmentand participated in the colonization of the surrounding lands through established commodity-money turnover and military intervention. The basis for asserting that Utopia is a non-existent society, or an imaginary country, is not.

\section{Colonatus}

And since More from the very beginning specifies that the Utopians "consider themselves more like holders than owners of these lands" (Th. More, 1998, p. 53), we dare to assert that in Utopia the colonial system was developed, a widespread form of using landed property since the time of the Roman Empire.

The Colon was not just attached to the ground, it was attached to the land of the lord who was interested in being promptly and properly cultivated..., and therefore the lord, from whom the state demanded the receipt of taxes, had to make every effort to force juridically free "Give out” in full, not particularly considering with his free juridical status, with juridical guarantees of his rights. (Fichmann, 1991, pp. 27-45)

And "the meaning of the word 'colon' is that it denotes the social-professional attachment of the colon as a landowner" (Carrier, 1983, p. 219; p. 231; p. 226; p. 228). Based on the research of the famous papyrologer and connoisseur of late antiquity, Carrier(1983) and Fichmann (1991) specified that the colonatus was not a consequence of socio-economic processes, but was a consequence of the taxing reform of Diocletian, based on capitation, which could have been collected only if the taxpayer was attached to its origo (origin), that is, under the condition of so-called adscription ("interlineations", or "registry", or in a more modern version of "registration”). Such a socio-professional attachment to the land, as described by More, as it turned out, existed long before the writing of Utopia, and in fact the Utopians, being "the holders of the land", were hostages of the fiscal location.

Fichmann's conclusions, which convince us in the correctness of the typological convergence, observed in the texts of More and Dionysius, can be reduced to the following: the colonial relations were established as a result of an accord (agreement), herewith for the enforcing it, the law provided for a number of additional 
conditions that took into consideration the interest of large landowners in a permanent and guaranteed labor force for the cultivation of land and which were aimed at attaching to the estate of the worker/tenant (Constitution, 244 AD. (Carrie, 1983, p. 212)), on the aspiration to keep the colonists and their offspring in the estate, supplementing the number of dependent colonists, disposing of on the basis of legal legislation by the offspring of the colonists from mixed marriages between free and colonists, and between the colonists of different lords, herewith the status of the colonists should have been documented, have a state qualification and not one lease agreement (contract as such), which was recorded as colonus homologus(415 AD), that is, the "colonus concerned with the contract". In fact, this is a contract service and we know that in the modern conditions of development of economic relations the "contract" as an "employment contract" is inclined to move: volatile and mobile - it transforms the colonus into a nomad.

Discovered by Fichmann, mutual benefit: both the colon (the holder) and the landowner-in preservation the colonial relations, guaranteeing the hereditary attachment of the colonists to the estate for the large landowner, and the colonists - the strength of holding, while the escape and harboring of the colonists severely punished, which was prescribed by the state in harsh terms, was reflected in the artistically constructed reality of the Utopian stated by T. More, where citizens were in certain economically-contractual relations with the employer, which provided observance a kind of archetypal, but normatively prescript, the LC-Labor Code (e.g., strict six-hour working day). However, the system of contractual relations, discovered in Utopia as a cast of Roman realities, is determined by the cult of Mithra, the god of agreement and consent. The cult of Mithra ${ }^{2}$ was widely spread outside of Iran, especially in the Roman Empire, where it was revered on a par with Jupiter or identified with Zeus. One of Mithra's epithets is the "straightener of lines (borders)", which not only refers to the possible and reconciling role in disputes about boundaries, but directly points to the function of the priest-king, which existed from ancient times. The priest-king took part in ritual dimensions, which not only allowed checking the adherence to the treatyas a universal law, but distinguished between truth and falsehood in observance of the balance between good and evil, which in turn allows us to consider that Mithra is a deity, defining moral boundaries, that is, a deity, creating and protecting the ethos of the people as the treaty system.

According to Fichmann, between the juridically free colonus and the state stood a large landowner-the owner of the land (dominus terrae), to which the colonus and its dominus were attached, and this allowed the landowner (lawfully and illegally) to dispose of the fate of the colonus, and therefore the probability is high that the colonus turned into an employee, dependent on a large estate, into a person of a "worse" status, and that in itself, as a degree of "negativity" of the perception of a person and citizen, that is, a person of a "worse" status, recognized by the state itself, had been conscious of by the colonus, and could be changed into a "deterioration"by the lord, depending on the level of its political and economic power. This is an unwritten "slavery", but a fixation, an attachment to the land, and, at the same time, to its owner (something similar to serfdom of peasants in Russ), when the right and duty of the lord to sell it with the land, to dispose of the fate of whole family, did not allow considering the colonus as virtually free. This is the first contradiction: bondage indirectly — the passage of "Utopia" sent to it, when the way of movement of the Utopians makes a slip in

\footnotetext{
${ }^{2}$ Mithra (av., “contract”, “consent”) is an ancient Iranian mythological character associated with the idea of a treaty, and also acting as the sun god. Mithra belongs to the Indo-Iranian pantheon: the name itself goes back to the Indo-European root, which is related to the designation of the idea of mediation, reciprocity, exchange (and measure), regularity, harmony, peace, friendship, sympathy (“Avesta”, Parthian and Sogdian Manichaean texts, Zoroastrian calendar, Buddhist iconography, Greco-Bactrian coins of Demetrius, “The Rigveda”, "Ramayana”).
} 
speaking, prescribing to citizens who are even in a short trip and allowed by the ruler himself, that is, in a temporary "detachment" from the land, register in the place stay and, according to the law about strict regulation of labor service, to work out the appointed time of his craft, otherwise they could not get a day's food (Th.More, 1998, p. 65). Let us note that in the state of Utopia there is a complex differentiation of labor: agriculture, animal husbandry, various handicrafts, construction (roads and town planning), weaving, trade, service personnel, education, etc., then we have an ordinary state with a complex infrastructure that works as well an established mechanism due to universal and compulsory labor without discounts on the social estate: All citizens and non-citizens perform labor and military service, and the existing fiscal supervisory authority keeps track of evasion of work and has a system of punishment of censure before departure to slavery (Th. More, 1998, p. 65). In short, the state as a state is no "Utopia", in terms of "illusion".

We read this Dionysius's passage:

The crowd of the poor ... ... At first, they led a life full of hardships, in the mountains under the open sky. But when they decided that they had become sufficiently numerous and fit for battle, they captured a well-fortified city, from where they began to ravage the entire district with raids. Against them, the consuls pulled out the army and without much difficulty mastered the city. Having punished with the birch and put to death the instigators of the riot, they sold the rest as booty. It so happened, that together with the other prey the land was sold in the previous year, and the silver, obtained from the sale, was shared among the citizens. (Dionysius. 2005. XX. XVII. (20.9)

This is a picture of the colonists, who fortified one's position in the status of the "worst”, preferring robbery rather than the treaty. I think for the reason that the owner of the land (dominus terrae), to which the colonus and its dominus was attached, exceeded its legitimacy, violating the agreement, exposing "personal interest", transforming them into a tumbleweed: mobile contractors-headhunters, who were always on the periphery of the policy in case of sudden "planned" overturns and revolutions. And this is an example of the failed "slave polis", when "peasant” ("rural”, "uncultured, rude, but members of Athenian society, and therefore having rights to landed property"), declassed (without land ownership) and weary of idleness, for attempting to organize a "slave policy", is punished beyond measure, deprived of citizenship, grotesque hatch into understanding: Why does the revolution eat its leaders? So, in the mirror perspectives of the past, More sought truth, but opened contradictions (practically as in Kipling's tale about the baby elephant, but in contrast to More, no one beats us, only cheating).

The Utopians of More, who revere Mithra, acted like the Avestan deity: like Greek gods, they interfered in human wars, descending from heaven, and restored justice by waging war beyond their state borders, as if guarding the inviolability of their territory and their laws, rejection of which, as well as encroachment on them, led to armed conflicts, the goal of which was the introduction of forced disciplina (established order), sanctioned by Mithra himself. The divine appeal restored the borders that had been violated because of permissiveness or non-compulsiveness, which resulted from the ignoring of contracts, that is, disrespect to God, and imposed punishment in the form of fines and contributions on account costs and moral damage. Description of military demarches (Th. More, 1998, p. 93), but rather the clarification of More to the contractual obligations of the Utopians, which in fact are the winged determinants of all military campaigns, would be read as an artistic fiction and would be perceived as a stylistic figure, if it had no analogues in the past (the texts of Dionysius, Appian, Caesar) and the future (all subsequent historical chronicles, documentary evidence, memoirs of participants in wars, verbatim report of the Nuremberg trial, reportages of international conflicts in the Near East, Africa, Asia Minor, Europe, compromising evidence on state departments in Internet, 
etc.). Exactly this identity allows us to consider Utopia as an expanded invective for the entire social order, regardless of time and place, and, in particular, for the state as a paramilitary mechanism of the improvement of public services of the human hostel, based on regulations that allow and, more often, provoke its violation, since destabilization is the driving force of existence. This polar complicity of Mithra in the war lurks in the very aporia of the world-war, which transforms the god of treaties into the chthonic deity of destruction and murder. Here is the second contradiction and the incised "half” of our frog.

\section{Nomadic Piracy}

Mitosis's division into nomads and settled was the first in a series of class, ethnic, social, caste, corporate, and other divisions that will fall to one's lot of humanity in its civilizational development. Some have flourished systemic chaos and others have a clear organization of life, which assumed a strict hierarchy of the hostel/clan. While the settled demonstrated their unavailability to properly organize their lives in a new place - an overgrown household would require developed means of transportation, nomads, on the contrary, easily removed from their seats, owning small ones, moving in small groups that provided mobility and maneuverability. Moreover, it should be noted that at the heart of piracy, which subsequently spread on the planet as a virus, lay the same spontaneity and chaotic movement of a group of people, not burdened with family ties.

So, the nomad adapts to the situation and the settled adapts the circumstances to himself, while the latter shows no less ingenuity than the first, and, since settled life demanded improvements not only in the arrangement of mode of life, but in entertainment and observance of order, then it gradually developed farming culture and irrigation, rock-painting, and epic legends as moderators of the traditions and education of youth. For the nomad, the danger was hidden by the unknown territory, which was still unknown to them, and a delayed-action mine waits for settled. This mine, buried in its own yard—security and stability of life, did not insure against civil strife between family members. The growing wealth of one of the settled people, who got the best land and who was more skillful in cultivating the soil, demanded his status quo-assertions in the rights with the subsequent right of continuity. So surpluses there were, than more insistently the power manifested itself: setting its own vertical and straightening the horizontal. Such obvious differences between settled and nomadic groups did not exclude their relationships. It was the nomads who acquaint the settled with the first skills of domesticating animals, as their own life proceeded in close contact with the living/wild nature. The further development of cattle breeding contributed to the emergence of commodity relations, at first, within the ethnos, creating the very precedent of dialogue in society. And if for the first it is important to dig a "treasure" out of the ground, and for the second - to bury a "treasure", the convergence of these vectors gave birth to Sophia, the very pre-philosophy that discovered the laws of nature to a man who, standing out for his equality in the sublunary world, discovered their responsibilities in biogenesis.

At the next stage of development, when the skill of movement was required, as wealth appealed to the expansion of its possessions to multiply and accrete with new sales markets, and the ripening demographic explosion forced to search lands for the colonies, the reaction of the settled towards the nomadic tribe takes place. A kind of exchange of technologies begins, as a result of which the settled began to apply the strategy and tactics of nomads - hunters and pirates, by and large, strengthening their money-grubbing way of life with a hierarchical structure and patronal way, mobile deterrence and suppression (armed detachments). The nomads, having adopted from the settled model of the social order-the family and strong tribal ties, accreting with 
wealth so that their camps acquired the traits of a protopolis, that is, practically rooting, regenerated into the essence of a "settled", began to implant their cult, trampling on the boundaries of the Other. Thus, how settled, confessing the cult of wealth and power, and nomads, conducting the policy of anarchic brotherhood, were mutated. Nomadic way of life was dissolved under the wheel of a clear organization of the first civilizations: Sumerian, Egyptian, Assyrian, Cretan. However, it arose with greater force in one millennium AD among the peoples of the Mongoloid race, as if anticipating that this way of life can arise and arise from time to time, like a kind of vaccine that is hidden in the noosphere of mankind until a threat of assimilation to any ethnic group does not arise. Then frequent and regular movements in space (in search of pastures or better shares), creating inconveniences for entrenched societies and showing a different way of life, begin to threaten to others by assimilating. And although my explanations are of nature of a speculative warning, the second "half" is incised - let us descry it only at the gleam of the historical map.

\section{Colonial Development of the World as Disciplina}

If the existing piracy of archaic tribes can be considered as a consequence of the nomadic way of life, which was favored by a certain part of the pra-humanity, which fell under the charm of the "bourgeois" polish of the settled, then the campaign to Troy should be perceived as the satisfaction of the geopolitical ambitions of the nomads who are not accustomed to the monotonous work - the Asia Minor fertile land with developed irrigation system, inherited from the Sumerians, attracted the Achaeans and the inhabitants of Argos, who lived in more than modest natural conditions, and the Denyen, as a result of the Santorini eruption turned up a scanty territory with the destroyed infrastructure of the former Crito-Mycenaean civilization. The eruptions of the Santorini volcano (from 1620 BC and for three centuries after the first and most powerful one) prevented the population of Crete, the Cycladic group islands, and the closely connected southern part of the Peloponnese to rearrange farm, collapsing in an economically catastrophe, as a result, they were forced to seek new lands and resources to restore their former power and influence. The campaigns for the "golden fleece" of Asia Minor were undertaken more than once, as evidenced by the archaeological excavations of Schliemann, who discovered more than one Troy, and seven - the city was restored after each raid in its original place, blossomed, and even more attractedresolute and cunning sea robbers, who were greedy for profit, by its eastern flavor. Homer’s phrase: “beware of Greeks bearinggifts” sounds not only as a warning of human perfidy, but as a characteristic of the ancient Greeks who are achieving their goal in anywise. According to Thucydides (1999), Hellas became Hellas only after the last joint campaign to Troy in 1320 BC, in which representatives of various tribes of Ancient Greece took part, pursuing their own mercenary goals: from solving the problem of overpopulation, from the depletion of natural resources to the accumulation of initial capital. That is, after realizing the common task and accomplishing some joint efforts, namely: a large-scale demarche of military forces involving all the available groups of troops and formations that were in the territory of the Aegean and Ionian basins, as Thucydides spoke out, as a result of "mutual contact with each other". The Trojan War became the Rubicon, after which a new Greek civilization began and the campaign itself became possible, as Thucydides asserted, only after the Greeks got settled with the sea.And this could only happen due to the influence of the Cretan culture, which was built on the sea priority (Thucydides, 1999, p. 34 (I, 4) ) Direct evidence that King Minos was not afraid of pirates, but most likely subordinated them to himself, is the fact that the Cretan cities, as shown by modern excavations, did not have defensive structures from the sea. And perhaps also because the robbery was an "ancient way of life" of the continental and riparian population, and 
Thucydides testified, "then the occupation was not considered shameful, rather, it brought even some glory", and noted that the custom of carrying weapons is the consequence of spread of piracy (Thucydides, 1999, p. 34 $(\mathrm{I}, 5)$ ).

Undoubtedly, the robbery business was popular, because by virtue of free morals, the temperamental ancient Greeks did not impose a ban on the profession, but some kinds of social activities were still blamed, maybe not explicitly, but with a clause: What is not forbidden, it is possible. Morals in the riparian zone were rugged-robberies. As the historian writes, as a result of long-standing piracy, the cities began to be built far from the sea inside the mainland, but this did not have any effect for educational purposes - the inhabitants of cities continued to plunder each other, referring tocoastal and, especially, islanders - the Carians and Phoenicians (Thucydides, 1999, p. 36-38.). The location of the main cities of Hellas-Athens, Tiryns, Mycenae, Sparta, Corinth, and the contents of the tombs: the method of burial with an abundance of weapons, betraying the way of life of the deceased, confirm these conclusions.

Small and spontaneous campaigns were replaced by massive expeditions of ethnic groups, well-equipped ${ }^{3}$ and with a considered legend of tactical seizure-the restoration of trampled honor, which corresponded even then to compensation for moral damage. So the myth (stealing the bride and transference it beyond the sea) was beginning to be used for political purposes, and religious views were freely corrected to pleasures of personal ambitions and geopolitical interests. Explaining the failures of the Hellenes under Troy, Thucydides justified them by the poverty of the attackers, which, in the light of our talk about travel, is close to the truth: The descendants of the Pelasgians, because of the economic crisis (ecological catastrophe and as a result of crop failure, overcrowding, lack of resources, decline of culture), really experienced material difficulties, otherwise they would not have decided to resort to frank expansion of Asia Minor territory, hoping for a correct profit, like pirates for luck (Thucydides, 1999,P. 34-35.(I, 11)). This explains the narrative minimum of military operations in the Iliad itself-apparently Homer disposed of scarce material because of his actual absence: The collisions were spontaneous, irregular as pirates, which allowed Thucydides to make the assumption that the Trojan War itself is insignificant, exaggerated poetic imagination. In the chapter "The Battle for the Wall”, the might of the defensive structures of the Achaeans is celebrated, showing not only fortification savvy, reinforcing the foundation with frequent piles, erecting "the highest visors", and providing the gate with “double locks” (Homer, 1990, Iliad, XII, p. 255), but also a certain skill in landscaping his camp, for they had unlimited time. Apparently, the Denyen, persecuted by thirst for profit, had no desire to fight forever for the stolen foreign wife: Agamemnon, seeing that the defense of the camp is broken, offers to save the remnants of the army by fleeing to their homeland: “... There is nothing wrong in flying ruin even by night...” (Iliad, XIV, p. 75). What is more, the speech itself produced man in the commander, brought up by piracy, inclined to change course to save the looted more than to death on the battlefield. Carefully reading the Iliad, it becomes noticeably Homer's ignoring the actual armed encounters in pleasures for the lyrical digressions and mythological anecdotes.

The Hellenic Wars, being, in fact, trivial piracy, were the geopolitical reconnaissance with the subsequent possible colonization, and therefore they demanded a kind of heroic nimbus, transferring them to the status of sacred battles, the death of which approximates to immortality. The military expansion of the Hellenes ended in

\footnotetext{
3 “That all the oarsmen were at the same time and the soldiers, can be seen from the ships of Philoctetes: All their oarsmen, according to Homer, were shooters from bows. ... and their vessels were not decked out, but rather, in an ancient way, they were built like piratical ships” (Thucydides, 1, 10).
} 
defeat—-their return "on the shield” (to return defeated) of their greed lasted for years (“Odyssey”), and even this strategic error did not moderate their passion for changing places. Solon, one of the seven wiseacre, a poet, legislator of Athens, who traveled a lot since his youth as a merchant, explained the craving for travel by the "human desire for profit that has no limit” and the recklessness of youth, mourning: “... who is richer than others nowadays, striving to double. Who is able to saturate all the citizens?”, and warning against moral errors: "The people's themselves prepare death, working hard for one money" (Golosovker, 2004), so the archon of Athens formed the world outlook of youth, future philosophers and historians, at a time, when "the war raged all around". The lyrics of the ancient Hellenes were, therefore, primarily heroic, that carried the experiences of desperate travelers, fearless warriors, expressed the hope of tireless romantics not only to find heaven on earth, but to make all the unspeakably rich, and therefore happy. That is why the poetic formula arises: "Money, money is a man" (Alcaeus of Mytilene). It was a great era of archaic entrepreneurship— “in it merchants were pirates, and pirates-merchants". ${ }^{4}$ And since in the ancient Greek language the word " $\alpha \theta \lambda o \sigma$ " had three meanings at the same time: struggle, labor, feat, such an active substitution in the lexicon says only one thing: Military art was a way of existence.

In describing the war, Homer does not even have a shadow of the elegiac of poets, who wrote with iambic: the eclectic vivid imagery, like Eisenstein's montage manner, with its swiftness and realism, force to turn away from the book as from the television broadcast of execution, the visible pictures of the greatest of poets are so expressive: “...even so furiously did Achilles rage, wielding his spear as though he were a god, and giving chase to those whom he would slay, till the dark earth ran with blood” (Iliad, XX, pp. 493-503), and Achilles's "invincible" hands (in the sense of "indestructible") draw an archival copy of the modern Robocop-so much he is "insatiable in war" (Iliad, V, p. 864): not only a shadow of divinity, under the mask of Ares, a mercenary, a fighter of foreign heads, a ferocious pirate, and therefore his army, like a flock of wolves, scouring in the field, hungry and irresistible ("Predatory beasts, in whom boundless insolence is in hearts" and because the poem can be considered both as an ideological order and as a moral teaching to posterity, which is obliged to build itself on the "fleet-footed Achilles" and "Ajax, bulging with anger". Apparently such greedy and impudent "black hunters" who lost their civil status and fell from a colonatus, scattered by a Tumbleweed, were enough in the Roman Empire-from them they collected cohorts of the "nomad colonatus"-a pirate who was on the rails of the colonist, along with the scalpel of the privative and terra nova). (And what kind of power was the educated "insurmountability", your own mind will tell you, need to see at the helmet, pierced in the battle at the Marathon, and found in the early 19th century-a hole from the shaft indicates that the spear has come in completely, breaking through the metal, frontal bone.)

And how do they fight at T. More? Tough and single-mindedly, like Caesar-affected the work with primary sources- “Commentaries on the Gallic War”.So the regulation of economic wars under the oldest motto "The purpose justifies the means" formally legalized the beginning of military actions caused by non-compliance with the treaty, which implied a threat of possible ruin or violation of the boundaries of freedom, whether rights or property.Then Utopus announced a campaign for "compensation for damage”, which the Utopians called "revenge for money insults"(Th. More, 1998, p.89), whose goal was to restore the "trampled" reputation of the state, in the absence of which "dishonor" should rather be composed in order to demand satisfaction, and, therefore, the consolidation and recognition of the other national credo of one Power

\footnotetext{
${ }^{4}$ Golosovker, Y.E. Poets and lyrics of Hellas and Rome. Golosovker, Y.E. Decree. op. p. 36.
} 
by the right of the strong. Allusions to today's military conflicts, in the center of which the USA appears to be "offended Utopus", are so obvious, and perhaps such "offenses" might look ridiculous due to the remoteness and geographical isolation of this state from most countries of the world, with which it is fighting and attacking, declaring, like Utopus, a long nose is hurt-“economic interest”, that is, deprived of common borders with "offenders", and the Utopians, I recall, waged wars only in foreign territories—and never on its own, if not real victims and ruined states, and if in fact there were no historical precedents of such vilification- "insults" inflicted on the nation's honor and led to real cruel wars, migratory flows forming conglomerates of ethnic groups, literally, re-order the political world map (e.g., the stolen Spartan virgin as the redeeming victim of Greek colonization in Asia Minor in the 13th century BC, where the very moment of "theft" is rather controversial, since all the maidens of Sparta were trained in martial arts on a par with men, it was possible to "steal" only with the kind consent of the girl,and the Spartan queen, legally marrying a stranger of the same rank as herself, was not deprived of honor, and therefore revenge broke away by the earthen crock, especially since the marriage with Paris was not fictitious, but lasted more than 10 years; or the possession of the relics of the founder of one cult (Christ from Nazareth) by representatives of another (Islam) was declared an unlawful and illegal act that acted as the strongest aphrodisiac in the struggle for the spheres of influence of the Carolingian dynasty and the spread of Christian ideology during the Crusades of the 10th-13th centuries, then faith was used as a lever of control and mass impact).

Since it is precisely in finding a balance between order and disorder through the conflict, that humanity painfully seeks excuses for its existence, the strategy of war used at the present stage of human development shows only one thing: the cult of Mithra remains the only revered cult of modernity, as the rulers of countries continue to identify their actions with function of God — the establishment of a universal law, in which the war, its principles and methods, is inscribed in the judicial and juridical framework of the state structure, for being a stimulus of compliance with contractual obligations, transubstantiate in kimberlite ore of economic well-being. The main function of Mithra - the union of people in a special social structure and the establishment of contracts between them-explained the distribution of such categories as mos maiorum, virtus, disciplina (Makhlayuk, 2010), which existed on the position of three whales - the very basis of the Roman state, whose social significance would not be wealthy without honoring the cult of Mithra, that is, without reliance on the call of ancestors, military valor, the established order. Since the time of Alexander the Great, after the Macedonian conquest of Iran and after the accession of the Ptolemaic dynasty, the Achaemenid cult of Serapis (emanation of Mithra), elevated to the royal cult - the cult of the "god of power", providing both mos maiarum, and virtus, and disciplina, determined a type of public system as an institutional model for all times and peoples. Trying on military habitus as mandatory armor-attribution of its far from peaceful existence, the More's Utopians, leading the brutal war-retaliation in adjacent territories, establishing strict discipline of work, and establishing fiscal supervision literally every citizen, we can say, "inherited" the unit of the ancient state, was tailored a "perfect example"-Utopia state, unattainable idealization of which was denied, because the reality, revealing examples of the "machinery of suppression" in the full specifics of the real historical time, permitted to recognize in it the prototype of the social order. The state as a machine of repression appears to be the only form of human community that has been used since ancient times, but is not exclusive, because the most important task of creating a "good" for the majority within the "state" remains impossible to this day. It follows from the foregoing that the Utopian state could not become a prototype of a perfect state, the ideal of which 
was the basis of the Utopian theory, since the supreme deity of the country, preferring the spirit of military valor to all peaceful "spirits", encouraged the strategy of the warrior in resolving contractual obligations—-the same "nomadic colonatus".

And now to the problems that lay by chord to our space of reasoning —one's/another's/alien—Is its share in the general crying for humanity so important? Is it dangerous? And if so, to whom? Or else, who cares about fears that are excited by this three-part incantation "your/alien/other", this tricolor of identification. Correspondence to whom and what? And in this regard, we recommend stopping all talk about tolerance-it does not exist, because it is defined as "toleration", that removes the issues of the "boundaries" of the Alien, dissolving and ignoring primarily the modus vivendiof the Other, that is, the existence of a neighbor that lives better. Therefore, Troy remains the only true and correct explanation of the nature of terrorism. If we stand for individuality, then why do we pretend, insisting on overcoming "alienation" and "otherness"? Why should we necessarily sway someone into "our" camp? This happens when the "stranger" is allowed in by opening the gates and welcoming his "happiness" as bread and salt, forgetting that even a tamed pelican will swallow other nestlings and believing that the proclaimed tolerance and individuality, underlying the social order, will serve a protective letter from every foreign rearguard.

The problem of terrorism lays not so much in the range of law, and not so much in the range of faith, but, I think, in what is called "legal conviction", when both "right" and "faith" appear in one bund, when one provides the safety of another, this is the moral right that was transmitted by the "law of ancestors" by faith in divine justice and by the rules of behavior - the moral law inside (the same Kantian principle). And this conviction necessarily consists of a sense of duty and responsibility to the Other, which, in turn, is impossible without respect for the Other. When a belief in a moral postulate (the call of ancestors) justifies for your "right” to your boundary of existence, then this "faith" obliges you not to violate the boundaries of the Alien, respecting it. The call of ancestors, military prowess and established order (mos maiarum, virtus, disciplina) served the guarantee of individual freedom from the time of the Assyrian kingdom, and they are the determinants of boundaries (all kinds) and are the guarantee of that "happiness" that everyone forms for himself independently.For everyone who is not afraid to be a stranger and keeps himself in his "otherness", without encroaching on the boundaries of the Other. Mithra, the god of boundaries, treaties, and wars, was known as the patron of the wise, and he ensured that people did not break contractual obligations. It can be said that now other gods are reigned bythe Absolute, but man, not having lost the need and ability of "faith", without losing the passion for superstition, suddenly believed in his own impunity, having got used to the practice of indulgences, and is convinced of his right to violate any obligations.

Alien space is searched only when, for obvious and implicit reasons, it ceases to like its own-hitherto native, unique, and unrepeatable. But the reason can also be quite objective-war, natural cataclysm. Then all that is left of the "house" is collected in a bundle, in a pocket—and beyond the threshold (if it is still there), taking with it its "own" space, as it was with Aeneas, that after the defeat of Troy, the loss of parents, hearth, kingdom, capturing a bundle with the "ashes of Priam", based on the Apennines a new kingdown of Aeneids - the future Great Rome. Fear and panic help clean up the territory, sometimes instantly, it was they who contributed to the affirmation of the Achaean tribes, but I believe, that Aeneas himself also resorted to them, crowding the Etruscans, freeing up the space for fugitives from the ruined paradise of Troy, caring for the restoration of his "house" (clan-tribe) on a new, alien land. 
The Ilion's bastions turned up a kind of martial arts school, after which its students, enriched by the experience of survival, opened the era of migration wars and, having entered into an internecine struggle for independence, developing piratical inclinations, doomed mankind to live by transition from war to revolution and back.The interaction of different peoples in the region of the coastal Asia Minor, beginning as a journey-invasion, was transformed into cultural interchange, but the war for the warring sides remained almost the only way of existence, as if the warring nations anticipated that further ethnic assimilation threatened the decline and extinction of ethnic groups, and therefore, created on its basis, the heroic and philosophical epic by Homer can be considered the first orientalist study, which, in turn, proved to be an invaluable source for a multidisciplinary discourse, a kind of poetic provocation that wove a system of representations about Antiquity as the cradle of civilizations. It can be concluded in this way that, from the earliest times, the "positive" evaluation of war as a useful practice, as a result of which the human character is tempered, and his consciousness is cruel, passing through the crucible of reassessment of former values, with strong support from philosophers (Heraclitus), only developed militaristic inclinations of mankind-the whole further history is a vivid confirmation of that: The war moved the world and the war is distant, suggesting a campaign, otherwise a journey, and the authorities thus sought and still found ways of its legitimacy—and in virtusand disciplina, that guarantee of divine predestination, and ensuring the legitimacy (system of contracts) and order (the state structure) — so the god of war (Mithra) continues to rule the state. Here is the third contradiction: Laws provoking wars - an baby elephant can get its proboscis -

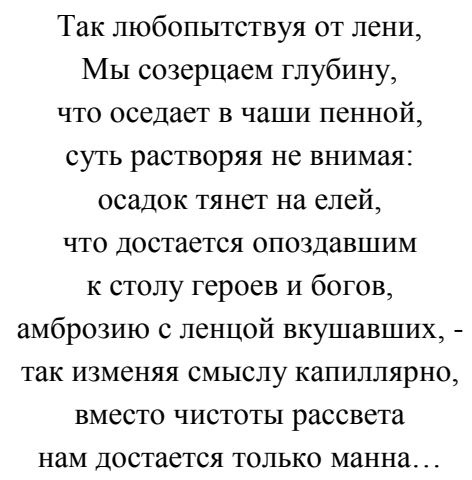

Learning to see the boundary of the Other is the vital necessity of the day to preserve the "person" in Man, to keep the Consciousness in health, to stop "escaping" into an identity that, as it turned out, is a wandering, timeless, between three pines (in three dimensions), in fact, from Deed/Action, from responsibility, vegetation in the immaturity and empty, but ringing, aggression, so as not to slip, like jellyfish, into slavery of material, which picked up the heads of the "spirit-poor" of consumption society, which becomes scanty of its own stupidity. It is necessary to return to the old "canons and laws"-the boundaries of existence, which are the norms of life reference points.

Modern lexical interpretations strongly link the meaning of the word "terrorism" to the word "terror" (fear), which someone once found in Aristotle's texts-there are no precise instructions, besides, Stagirus himself passed the real horror of "second birth", having passed captivity of strangers interpretations and dozens and hundreds of translations. And, as a rule, the true meaning of words is stored by a stable unit, fixed on the tail of winged expressions. The dictionary of Latin proverbs tells us: "TERRA incognita" is an unknown land, and "TIMOR est emendator asperrimus"-fear—is the most severe mentor (Kupriyanova \& Umnova, 1996). As we 
can see, the denoters are different- the word "fear" in Latin had completely different inscriptions. Is there another discrepancy or dexterous manipulation? And since, the habit of frightening and fearing is thriving, the fear is, indeed, the emendator asperrimus.

\section{References}

Carrier, J.-M. (1983). Un roman des origines: les genealogies du “colonat du Bas-Empire” Opus. (p. 212; p. 219; p. 231; p. 226; p. 228).

Dionysius of Halicarnassus. The Roman antiquities. In 3th vols. T. II. Translate from ancient Greek under the edition by I. L. Mayk. - M., 2005. [The Roman Antiquities of Dionysius of Halicarnassus. Translate from Latin by L. Biragi. 1480]

Fichmann, I. F. (1991). The late Roman colonatus-Is a myth created by historians (pp. 27-45)? VDI[JOURNAL OF ANCIENT HISTORY]. 1991. № 1.

Golosovker, Y. E. (2004). Anthology of ancient lyrics in Russian translations. Lyrics of Hellas. The Second book. Tomsk-M: Aquarius Publishers.

Greek polyortics. Vegetius. St. Petersburg: Aletheia, 1995 [“Abhandlungen d. K. Gesellschaft d. Wissenschaft” zu Gottingen (Philologisch-historische Klasse. Neue Folge. B. IX-XII, Berlin, 1909-1912 “La poliorcetique des grecs”. Paris, 1867]

Homer. The Iliad. Translate from the Ancient Greek by N. I. Gnedich (1813-1829). L.: Nauka (Science), 1990.

Kupriyanova, V., \& Umnova, N. (1996). A brief dictionary of Latin words, abbreviations and expressions. Moscow: TERRA.

Makhlayuk, A.V. (2010). Spirits of ancestors, valor and discipline: Sociocultural and ideological aspects of ancient military history in the latest historiography. VDI [JOURNAL OF ANCIENT HISTORY], 2010. № 3. (pp. 141-159)

Menshikova, E. (2012). The receptive curse or terminological failure: To the problem of interpretations of the T. More's neologism “utopia”. Credonew, № 3, №4.

Menshikova, E. (2016). To the problem of interpretations of the neologism "utopia”. Antiquity as a genome of European and Russian culture. St. Petersburg: Aletheia (pp. 237-282).

Menshikova, E. (2018a). The discursive gene of travel. E. Menshikova. Myth: the resistance of the material. St. Petersburg: Aletheia.

Menshikova, E. (2018b). Troyan terrorism: Revenge of the colonists or the condition of evolution (to the problem "Your/Alien”) (pp. 183-215). Credonew, № 1.

More, Thomas (1998). The Utopia. Epigrams. The story of Richard III (p. 53). Moscow: Nauka (Science). [The Complete Works of St. Thomas More. Vol. 4 Eds. Edw. Surtz, S. J. and J. H. Hexter. New Haven; L., 1965; Prevost A. L’Utopie de Thomas More Mame. P., 1978]

Thucydides. History. Translate from the Ancient Greek by F. G. Mischenko (1887-1888). St. Petersburg, 1999 [Thucydides and

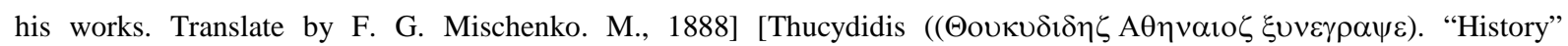

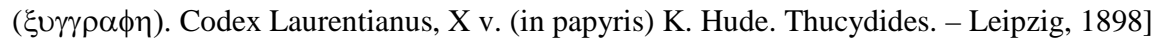

